\title{
Pengaruh employee relation terhadap motivasi kerja karyawan di u pashaa seminyak
}

\author{
I Gusti Agung Ayu Nita Setianingsih ${ }^{1)}$, Agus Muriawan Putra ${ }^{2)}$,Putu Ratih Pertiwi ${ }^{3)}$ \\ Program Studi Diploma IV Pariwisata, Fakultas Pariwisata, Universitas Udayana ${ }^{123)}$ \\ Jalan DR. R. Goris No.7, Denpasar, Kode Pos: 80232 \\ Email: nitasetianingsih33@gmail.com
}

\begin{abstract}
Abstrak
Sebagai hoteldengan tingkat occupancy diatas $50 \%$ setiap tahunnya, U Pa asha Seminyak dalam opera sionalnya tentu tak luput darikomplain. Berdasarkan data yang tercatat, jumlah komplain menin gkat dalam satu tahun terakhir. Haltersebut mengindikasikan bahwa kualitas kinerja karya wan menurun, serta disiplin karyawan y ang masih kurang terkait absensi dan waktu bekerja sehingga pihak manaje men berupaya meningkatkan motivasi kerja karyawan guna meningkatkan kembali produktivitas dan sikap disiplin kary awan melalui employee relation. Sehingga tujuan penelitia niniuntuk mengetahuipenera pan program employee relation serta pengaruhnya terhadap motivasi kerja karyawan. Teknik pengu mpulan data yang digunakan yaitu observasi, wa wancara, kuesuioner, studi kepustakaan dan dokumentasi. Teknik pen entuan sa mpel menggunakan proportional stratified sampling dengan sampel sebanyak 80 responden. Da ta diolah denga n program SPSS 24 . Teknik analisis da ta yaitu uji va liditas, uji reliabilitas, analisis regresi se de rh ana, serta ujit-test dengan taraf signifikan sebesar 5 persen. Progra m employee relation yang dilaksanakan unt uk meningkatkan motivasi karyawan antara la in Program Pendidikan dan Pelatihan, Program Penghargaan, Program Acara Khusus, Employee Communication Program, Profit Share, dan Employee Attitu de Survey. Ha sil uji hipotesis menyatakan bahwa variabele mployee relation berpengaruh positif dan signif ik an terhadap variabel motivasi kerja karyawan karena diperoleh nilai signifikansi $0,000<0,05$, nila i ko e fisien regresi sebesar 0,626 bernilai positif dan nilait hitung lebih besar dibandingkan $t$ tabel 9,726 $>1,991$. Oleh ka rena itu progra $\mathrm{m}$ employee relation perlu dilaksanakan karenaberhasil meningkatkan motivasi kerja karyawan di U Pa a sha Seminyak.
\end{abstract}

Kata Kunci ～: Hubungan Karyawan, Motivasi Kerja, Hotel

\begin{abstract}
As a hotel with an occupancy rate above $50 \%$ every year, U Paasha Seminyak in its operations certainly does not escape complaints. Based on recorded data, the number of complaints has increased in the past year. This indicates that the quality of employee performance has decreased, and employee discipline is still lacking in relation to absenteeism and working time so that managementseek s to in crea se employee motivation to improve employee productivity and discipline through employee relations. The a ims of this study was to determine the application of employee rela tions and their influence significantly on em ployee work motivation. Data collection techniques used were observation, interviews, question naires, litera ture study and documentation. The sa mpling technique uses proportional stra tified sampling with a sample of 80 respondents. The data is processed u sing SPSS 24. Da ta analy sis techniques are validity, reliability, sim ple regression analysis, and t-test with a significant level of 5 percent. Employeerela tions programs implemented to improve employee motivation include the Education and Training Program, the Award Program, Special Program Programs, the Employee Communication Program, the Profit Share, and the Employee Attitude Survey. Hy pothesis test results state that the employee relations variable has a positive and significant effect on employee work motivation variables because a significance value of $0,000<0.05$ is obtained, a regression coefficient of 0.626 is positive and the $t$ value is greater than $t$ table $9.726>1.991$. Therefore the em ployee rela tions program needs to be implemented because it has succeeded in increasing the work motiv ation of employees at U Pa asha Seminyak.
\end{abstract}

Keywords : : : : 


\section{PENDAHULUAN}

Pulau Bali sejak dahulu sudah sangat terkenal akan keindahan alam, keramahan penduduk, serta kekayaan budaya yang masih sangat kental di beberapa daerah dan tidak terpengaruh oleh moderenisasi masa kini.Selain karena faktor tersebut, tersedianya fasilitas akomodasi serta sarana dan prasarana penunjang kepariwisataan bagi wisatawan yang berkunjung ke Bali merupakan kesempatan yang sangat bagus untuk mata pencarian penduduk dan menambah banyaknya wisatawan yang ingin datang ke Bali yang menyebabkan pariwisata di Bali semakin berkembang dan tentu saat ini pun parwisata Bali masih tetap dilakukan upaya pengembangan agar menjadi lebih baik dari sebelumnya. Selain Bali memiliki faktor-faktor yang menjadi daya tarik seperti kebudayaan, adat istiadat, dan keindahan alamnya, Bali juga memiliki fasilitas-fasilitas penunjang kepariwisataan yang membuat meningkatnya aktivitas pariwisata yang terjadi di Bali, dan setiap tahunnya Bali mengalami peningkatan jumlah kunjungan wisatawan baik wisatawan domestik maupun mancanegara dan tentunya dengan motivasi kunjungan yang berbeda-beda. Hal ini dapat dilihat pada Tabel 1 berikut.

Tabel1. Kunjungan Wisatawanke Bali Tahun 2014-2018

\begin{tabular}{|c|c|c|c|c|}
\hline No & Tahun & $\begin{array}{c}\text { Wisatawan Domestik } \\
(\text { Orang) }\end{array}$ & $\begin{array}{c}\text { Wisatawan Mancanegara } \\
(\text { Orang })\end{array}$ & $\begin{array}{c}\text { Total Seluruhnya } \\
\text { (Orang) }\end{array}$ \\
\hline 1 & 2014 & 6.392 .460 & 3.776 .638 & 10.159 .098 \\
\hline 2 & 2015 & 7.147 .100 & 4.001 .835 & 11.148 .935 \\
\hline 3 & 2016 & 8.643 .680 & 4.927 .937 & 13.571 .617 \\
\hline 4 & 2017 & 8.753 .633 & 5.697 .739 & 14.433 .372 \\
\hline 5 & 2018 & 8.948 .162 & 6.102 .014 & 15.050 .176 \\
\hline
\end{tabular}

Sumber: Badan Pusat Statistik Provinsi Bali (2019)

Berdasarkan Tabel 1 dapat dilihat bahwa kunjungan wisatawan terus mengalami peningkatan setiap tahunnya. Meningkatnya jumlah wisatawan mancanegara dan nusantara yang datang ke Bali maka secara tidak langsung hal tersebut telah memberikan dorongan untuk menyediakan tempat tinggal bagi wisatawan yang datang di Bali sehingga sampai saat ini pemangku kepentingan pariwisata di Bali sedang gencar-gencarnya melakukan pengembangan pariwisata dan melakukan pembangunan sarana akomodasi sebagai tempat tinggal dan kebutuhan wisatawan yang datang ke Bali dan seperti yang telah diketahui bersama pemerintahpun dengan mudahnya memberikan izin atas pembangunan akomodasi-akomodasi penunjang kegiatan pariwisata tersebut.

Kabupaten Badung merupakan salah satu kabupaten yang mendapat pengaruh dari perkembangan pariwisata di Bali. Perkembangan pariwisata di Kabupaten Badung tentunya disertai dengan meningkatnya sarana dan prasarana akomodasi seperti villa, hotel dan restaurant, beach $c l u b \&$ bar, serta penunjang pariwisata lainnya khususnya daerah tujuan wisata yang berlokasi di sebelah Utara kawasan wisata Legian, Kuta yaitu Seminyak. Perkembangan pariwisata di Seminyak Bali sangat luar biasa dan Seminyak pun dapat menjadi barometer wisata high end di Bali. Sekitar 15 tahun yang lalu Seminyak merupakan sebuah desayang kalah berkembang dengan kawasan wisata Legian, Kuta. Dulu Seminyak sangat banyak dengan areal persawahan namun 
sekarang telah berubah menjadi areal yang dipadati dengan fasilitas-fasilitas pendukung dalam kepariwisataan seperti restaurant, bar, private villa, dan hotel-hotel non bintang hingga hotel-hotel berbintang. Salah satunya adalah Hotel U Paasha Seminyak yang merupakan salah satu hotel berbintang empat yang berada di kawasan Oberoi Bali. U Paasha Seminyak berdiri dibawah naungan Absolute Hotel Service (AHS) yang berkantor pusat di Bangkok, Thailand dan sudah beroperasional sejak tahun 2012. Dengan pelayanan yang dimiliki, banyak wisatawan yang memilih U Paasha Seminyak sebagai tempat untuk berlibur bersama pasangan dan keluarga. Selain U Paasha Seminyak menyediakan sarana dan prasarana mewah mereka juga memiliki butler attendant yang siap melayani setiap tamu yang menginap. Banyak hotel berbintang empat pada umumnya tidak memiliki butler service, dan pada umumnya butler service hanya ditemukan di hotel-hotel berbintang lima dan sekelasnya seperti boutique hotel. Meskipun hanya hotel bintang empat dengan jumlah kamar 99 U Paasha Seminyak memiliki butler service dalam melengkapi pelayanannya dan hal tersebut yang menjadikan U Paaasha Seminyak mempunyai potensi untuk menarik wisatawan untuk menginap, hal tersebut dapat dilihat dari tingkat hunian kamar U Paash a Seminyak pada Tabel 2 berikut.

Tabel 2.Tingkat Hunian Kamar / Occupancy U Pa asha SeminyakTahun 2014-2018

\begin{tabular}{|c|c|c|}
\hline Tahun & Tingkat Occupancy (\%) & Pertumbuhan(\%) \\
\hline 2014 & 75,73 & 2,85 \\
\hline 2015 & 77,94 & 5,75 \\
\hline 2016 & 82,67 & $-4,00$ \\
\hline 2017 & 79,40 & 7,32 \\
\hline 2018 & 86,74 & 2,96 \\
\hline Rata-rata & 80,49 & \\
\hline
\end{tabular}

Sumber :Sales and Marketing U Paa sha Seminyak (2019)

Tabel 2 menunjukkan bahwa tingkat hunian kamar di U Paasha Seminyak selama 5 tahun terakhir terdapat penurunan tingkat hunian kamar (occupancy) pada tahun 2017 sebesar $4 \%$ yang di sebabkan karena sepinya kunjungan wisatawan ke bali karena memang sedang terjadinyatravel warning bagi para turis yang akan datang ke Bali pada saat peristiwa Gunung Agung di Kabupaten Karangasem sedang mengalami erupsi. Kemudian di tahun-tahun lainnya occupancy U Paasha Seminyak mengalami peningkatan yang berbeda-beda, dengan peningkatan occupancy tertinggi yaitu terjadi pada tahun 2018 yaitu sebesar 7,30\%. Meskipun tingkat hunian kamar hotel (occupancy) selalu tinggi, dan terlebih lagi jika hotel dengan tingkat occupancy diatas $50 \%$ setiap tahunnya tentu dalam operasionalnya tentu tak akan luput dari keluhan / complain dari tamu (guest complain). Hal tersebut dapat dibuktikan bahwa tak sedikit dalam operasional sehari-hari ditemukan tamu-tamu yang menginap meminta refund yang disebabkan oleh komplain sebagai kompensasi atas kualitas pelayanan yang kurang memuaskan tamu tersebut. Jelas hal itu akan sangat berpengaruh besar pada pendapatan hotel (hotel revenue) karena pengembalian dana yang terjadi (refund) tersebut walaupun hanya sebagian persen saja yang dikembalikan. Jika sampai terjadi refund berarti tingkat keluhan tamu tidaklah dapat dianggap remeh karena pihak manajemen harus memutuskan untuk melakukan refund dari beberapa persen biaya yang telah dibayarkan oleh 
tamu sebagai kompensasinya dan agar tamu tidak merasa jera serta ingin kembali menginap lagi di lain waktu. Selain itu, bentuk ganti rugi dari ketidak puasan atau ketidak nyamanan tamu tersebut biasanya juga dapat diberikan dalam bentuk complimentary seperti free treatment tertentu di SPA.

Komplain dapat bersumber dari beberapa faktor diantaranya karena faktor pelayanan yang diberikan, komplain terkait fasilitas kamar maupun fasilitas hotel, complain terkait karyawan yang memberikan pelayanan, dan komplain-komplain yang bersifat khusus (Damayanti, 2015:138). Berikut ini merupakan data jumlah keluhan tamu (guest complain) berdasarkan jenis keluhannyayang terjadi di U Paasha Seminyak dapat di lihat pada tabel berikut :

Tabel3.Data Keluhan Tamu (Guest Complaint)U Pa asha Seminyak 2018

\begin{tabular}{|l|c|c|c|l|}
\hline \multirow{2}{*}{ Bulan } & \multicolumn{4}{|c|}{ Complain } \\
\cline { 2 - 5 } & Service & Facilites & Staff & Un usual Complain \\
& $(\mathbf{\%})$ & $(\boldsymbol{\%})$ & $(\boldsymbol{\%})$ & \\
\hline Januari & 4,8 & 5,7 & 4,8 & 3,8 \\
\hline Februari & 5,4 & 3,6 & 7,1 & 2,6 \\
\hline Maret & 7,8 & 8,3 & 5,4 & 2,4 \\
\hline April & 9,2 & 2,2 & 3,0 & 3,0 \\
\hline Mei & 7,4 & 4,4 & 4,9 & 1,2 \\
\hline Juni & 3,2 & 3,2 & 1,4 & - \\
\hline Juli & 3,8 & - & 5,6 & - \\
\hline Agustus & 8,6 & 7,8 & 6,7 & - \\
\hline September & 7,8 & 8,2 & 5,0 & 7,1 \\
\hline Oktober & 4,6 & 7,7 & 3,4 & 3,4 \\
\hline November & 6,8 & 6,5 & 4,0 & 4,0 \\
\hline Desember & 10,3 & 4,8 & 8,7 & 1,1 \\
\hline Jumlah & $\mathbf{7 9 , 7}$ & $\mathbf{6 2 , 4}$ & $\mathbf{6 0}$ & $\mathbf{2 8 , 6}$ \\
\hline Sumber: & & & & \\
\hline
\end{tabular}

Sumber: U Pa asha Seminyak (2019)

Berdasarkan Tabel 3 terdapat empat kategori komplain, yang pertama komplain terhadap pelayanan (service). Service yang dimaksudkan dalam hal ini merupakan pelayanan yang diberikan oleh karyawan kepada tamu, apakah memuaskan atau tidak dan dapat dilihat bahwa jenis keluhan tamu yang paling sering terjadi yaitu keluhan terhadap pelayanan (service) yang diberikan dengan persentase tertinggi dari tiga keluhan lainnya yaitu sebanyak $79,7 \%$ dalam satu tahun yaitu pada periode Januari-Desember 2018. Hal ini dikarenakan motivasi kerja karyawan masih belum maksimal sehingga sering mengakibatkan kesalahan yang menyebabkan komplain karena tamu merasa tidak puas akan pelayanan (service) yang diberikan oleh karyawan. Kemudian jenis komplain yang kedua yaitu komplain terkait fasilitas, baik fasilitas di dalam kamar, maupun 
fasilitas umum yang ada di lingkungan hotel. Selanjutnya yang ketiga yaitu komplain terkait karyawan/staff, yang dimaksudkan dengan komplain terhadap karyawan/staff yakni lebih mengacu ke arah staff personalities, yang dimana tamu merasa kecewa terhadap sikap dan kepribadian dari karyawan tersebut seperti contohnya karyawan kurang ramah saat bertemu tamu, bersikap ketus, kurang perduli dan kurang peka akan hal-hal kecil yang menyangkut tamu tersebut, dan juga menyangkut penampilan karyawan (personal grooming) dari karyawan tersebut. Sedangkan untuk keluhan yang jarang terjadi ( un usual complaint) yaitu keluhan-keluhan yang bersifat khusus yaitu dengan persentase sebesar $28,6 \%$. Keluhan-keluhan yang bersifat khusus (un usual complain) disini berarti komplain yang bersifat tidak biasa, dan sangat jarang terjadi seperti tamu kehilangan atau kemalingan barang saat berada di hotel.

Walaupun tingkat komplain yang terjadi tiap tahunnya terbilang masih cukup tinggi namun U Paasha Seminyak selalu bisa mencapai revenue goals yang telah ditetapkan sehingga hal tersebut akan mempengaruhi service yang akan diterima oleh karyawan sebab U Paasha Seminyak selalu menerapkan istilah "great revenue is a great service". Keberhasilannya U Paasha Seminyak tersebut dengan memperoleh revenue goalstidak terlepas dari peranan dari departmentdepartmentyang mendukung operasional dan tentunya tidak lepas dari peranan Sumber Daya Manusia sebagai roda penggerak operasionalnya. SDM yang berkualitas akan menciptakan keberasilan, khususnya dalam industry hospitality sehingga dalam hal ini kinerja karyawan memiliki peranan yang sangat penting dalam rangka meningkatkan kualitas pelayanan jasa. Berikut ini merupakan jumlah tenaga kerja yang bekerja di U Paasha Seminyak per department.

Tabel4. Jumlah Karyawan di U Paa sha Seminyak Tahun 2019

\begin{tabular}{|c|l|c|}
\hline No & \multicolumn{1}{|c|}{ Department } & Jumlah Karyawan (Orang) \\
\hline 1 & Executive Officer & 3 \\
\hline 2 & Human Resources & 7 \\
\hline 3 & Sales andMarketing & 15 \\
\hline 4 & Finance\& Accounting Department & 3 \\
\hline 5 & IT & 13 \\
\hline 6 & Front Office & 13 \\
\hline 7 & Buttler Attendant & 7 \\
\hline 8 & Engineering & 4 \\
\hline 9 & SPA \& Recreation & 19 \\
\hline 10 & F\&B Admin & 17 \\
\hline 11 & Food \& Beverage Service & 8 \\
\hline 12 & Food \& Beverage Product & \\
\hline 13 & Security & \\
\hline & & \\
\hline
\end{tabular}




\begin{tabular}{|c|l|c|}
\hline 14 & Housekeeping & 21 \\
\hline & TOTAL & 144 \\
\hline
\end{tabular}

Sumber: Human Resources U Paasha Seminyak (2019)

Berdasarkan pada Tabel 4 terkait jumlah karyawan U Paasha Seminyak dapat dilihat bawha U Paasha Seminyak memiliki karyawan sebanyak 144 yang terbagi dalam 14 departemen yang berbeda, dan seluruh karyawan tersebut merupakan karyawan tetap U Paasha Seminyak. Sebuah perusahaan tentu harus memiliki karyawan yang berperan sebagai roda penggerak perusahaan untuk dapat mencapai keberhasilan. Untuk dapat mencapai keberhasilan tersebut harus dipastikan operasional hotel harus berjalan dengan baik, sehingga diperlukannya SDM yang berkualitas. Berdasarkan hasil wawancara dengan Human Resources Department U Paasha Seminyak, diperoleh informasi bahwa telah terjadi penurunan motivasi kerja karyawan yang dapat dibuktikan melalui tingginya tingkat komplain yang terjadi, sering terjadinya ketidak tepatan waktu penyelesaian pekerjaan oleh karyawan, dan tingginya absensi karyawan, serta masih terdapat beberapa karyawan yang merasa kewalahan dalam mengatasi seluruh keinginan tamu-tamu serta untuk dapat menyelesaikan pekerjaan tepat waktu.

Dalam membangun Sumber Daya Manusia yang berkualitas manajemen hotel perlu memulainya dari segi internal yaitu melalui employee relation. Dalam penelitian ini employee relation bukan hanya dilihat dalam pengertian sempit yaitu semata-mata hubungan internal antar karyawan dalam suatu perusahaan, namun pengertiannya lebih dari itu karena employee relation itu sendiri sesungguhnya merupakan bagian dari kegiatan-kegiatan humas internal yang diterapkan oleh manajemen untuk membangun motivasi para karyawan melalui program-program yang ada dalam employee relation tersebut. Untuk membangun hubungan antar karyawan ini maka pihak manajemen menerapkan sejumlah program-program yang ada dalam employee relation yang diharapkan mampu meningkatkan motivasi kerja karyawan dan keharmonisan hubungan antar sesama karyawan yang nantinya akan berdampak pada perusahaan. Melalui program-program yang dimiliki employee relation dan setiap tahunnya didukung oleh partisipasi karyawan di dalamnya, maka dengan hal ini diharapkan dapat meningkatkan dan membangun motivasi karyawan dalam melakukan pekerjaan. Bercermin dari permasalahan tersebut, beberapa tujuan dari motivasi diantara merupakan meningkatkan semangat kerja dan juga kedisiplinan karyawan. Maka dalam hal ini motivasi akan dapat dikatakan sudah berjalan dengan baik apabila tujuan dari motivasi itu sendiri telah berhasil dicapai, dan salah satu dari tujuan tersebut yaitu membuat karyawan memiliki semangat kerja yang tinggi atau dengan kata lain motivasi memiliki tujuan secara positif untuk membangun semangat kerja karyawan.

Selain semangat kerja, kedisiplinan karyawan juga sangat penting guna mengukur dan mengetahui apakah dalam diri karyawan sudah tertanam motivasi secara maksimal, dan untuk mengetahui hal tersebut maka akan dilihat berdasarkan tingkat absensi karyawan guna mengetahui seberapa baik atau buruknya kondisi sumber daya manusia pada suatu perusahaan dengan cara melakukan kontrol ketidak hadiran karyawan. Berikut record absensi karyawan di U Paasha Seminyak dapat dilihat pada Tabel 5 berikut. 
Tabel5.Record Absensi Karyawan di U Paa sha Seminyak

\begin{tabular}{|l|c|c|c|c|c|c|}
\hline \multicolumn{1}{|c|}{ Bulan } & $\begin{array}{c}\text { Jumlah } \\
\text { Karyawan } \\
\text { (orang) }\end{array}$ & $\begin{array}{c}\text { Hari } \\
\text { Kerja } \\
\text { (hari) }\end{array}$ & $\begin{array}{c}\text { Absensi } \\
\text { Karyawan } \\
\text { (orang) }\end{array}$ & $\begin{array}{c}\text { Tingkat } \\
\text { Absensi }\end{array}$ & $\begin{array}{c}\text { Karyawan } \\
\text { Terlambat } \\
\text { (orang) }\end{array}$ & $\begin{array}{c}\text { Nilai } \\
\text { Keterlambatan }\end{array}$ \\
\cline { 2 - 7 } & $\mathrm{A}$ & $\mathrm{B}$ & $\mathrm{C}$ & $\begin{array}{c}\mathrm{D}= \\
\text { C/AxB }\end{array}$ & E & F= E/AxB \\
\hline Januari & 137 & 23 & 30 & 0.009 & 15 & 0.005 \\
\hline Februari & 142 & 21 & 32 & 0.011 & 23 & 0.008 \\
\hline Maret & 142 & 23 & 29 & 0.009 & 21 & 0.006 \\
\hline April & 142 & 22 & 35 & 0.011 & 24 & 0.008 \\
\hline Mei & 144 & 23 & 25 & 0.008 & 19 & 0.006 \\
\hline Juni & 144 & 22 & 31 & 0.010 & 22 & 0.007 \\
\hline Juli & 144 & 23 & 48 & 0.014 & 16 & 0.005 \\
\hline Agustus & 144 & 23 & 45 & 0.013 & 8 & 0.002 \\
\hline September & 144 & 22 & 26 & 0.008 & 11 & 0.003 \\
\hline Oktober & 144 & 23 & 22 & 0.007 & 18 & 0.005 \\
\hline November & 144 & 22 & 21 & 0.007 & 9 & 0.003 \\
\hline Desember & 144 & 23 & 33 & 0.010 & 12 & 0.004 \\
\hline Total & 1710 & 270 & 389 & 0.117 & 198 & 0.062 \\
\hline Rata-Rata & $\mathbf{1 4 2 , 5}$ & $\mathbf{2 2 , 5}$ & $\mathbf{3 2 , 4 1}$ & $\mathbf{0 . 0 0 9}$ & $\mathbf{1 6 . 5}$ & $\mathbf{0 . 0 0 5}$ \\
\hline Sumber & & & & & & \\
\hline
\end{tabular}

Sumber: Human Resources Department U Paasha Seminyak(2019)

Menurut Andarana 2012 (dalam Octanisa 2018) absensi dengan standar tingkat persentase sebesar 2-3\% termasuk ke dalam kategori kedisiplinan yang buruk, sehingga diharapkan tingkat absensi karyawan tidak akan melebihi dari standar tersebut. Dapat dilihat pada Tabel 1.7, nilai rerata dari tingkat absensi karyawan dalam satu tahun yaitu 0.009, sedangkan nilai rerata untuk keterlambatan karyawan yaitu 0.005 yang dimana hal ini menandakan bahwa tingkat absensi karyawan di U Paasha Seminyak tidak melebihi angka standar yang telah ditetapkan yakni berkisar pada 2 - 3\% oleh karena itu tingkat absensi karyawan U Paasha Seminyak tergolong dalam kategori baik.

Selain itu, gejala aktivitas SDM yang kurang baik yang disebabkan karena motivasi kerja karyawan yang menurun yakni dapat diperhatikan melalui tingkat turn overintention pada perusahaan tersebut. Motivasi kerja yang kurang maksimal maka akan menimbulkan keinginan 
karyawan untuk berhenti dari pekerjaannya tersebut. Berikut ini merupakan data tingkat turnover intention karyawan di U Paasha Seminyak.

Tabel6.Tingkat Turn Over Intention Karyawan di U Pa asha Seminyak Tahun 2015-2018

\begin{tabular}{|c|c|c|c|c|}
\hline Tahun & $\begin{array}{c}\text { Total } \\
\text { Karyawan } \\
\text { Awal } \\
\text { (Orang) }\end{array}$ & $\begin{array}{c}\text { Karyawan } \\
\text { yang Keluar } \\
(\text { Orang) }\end{array}$ & $\begin{array}{c}\text { Karyawan yang } \\
\text { Masuk } \\
\text { (Orang) }\end{array}$ & $\begin{array}{c}\text { Total Akhir } \\
\text { Karyawan } \\
\text { (Orang) }\end{array}$ \\
\hline 2015 & 141 & 4 & 3 & 140 \\
\hline 2016 & 139 & 6 & 5 & 139 \\
\hline 2017 & 139 & 2 & 4 & 141 \\
\hline 2018 & 141 & 4 & 7 & 144 \\
\hline Jumlah & $\mathbf{5 6 0}$ & $\mathbf{1 6}$ & $\mathbf{1 9}$ & $\mathbf{5 6 4}$ \\
\hline
\end{tabular}

Sumber: Human Resources U Pa asha Seminyak (2019)

$$
\begin{aligned}
& \text { T0 }=\frac{\text { Total Karyawan di Terima }- \text { Total Karyawan Keluar }}{\frac{1}{2}(\text { Total Jumlah Karyawan Awal }- \text { Total Jumlah Karyawan Akhir })} \\
& \mathrm{TO}=\frac{19-16}{\frac{1}{2}(560+564)} \times 100 \%=0,0053
\end{aligned}
$$

Berdasarkan data pada Tabel 6, dan rumus perhitungan turnover intention dapat dilihat bahwa tingkat turnover intention karyawan di U Paasha Seminyak hanya sebesar 0,005 atau sebesar 1\%. Widjaja (2008) memberikan sebuah teori yakni jika tingkat turnover intention pertahun mencapai $10 \%$ maka tingkat turnover intention perusahaan tersebut tergolong pada kategori yang tinggi. Dalam hal ini tingkat turnover intention di U Paasha Seminyak masih tergolong rendah, karena jumlah karyawan masuk dan karyawan keluar serta perputaran jumlah karyawan yang masih terbilang stabil karena mengingat terjadinya penurunan motivasi kerja karyawan di U Paasha Seminyak.

Mengarahkan daya serta potensi agar karyawan dapat bekerja mencapai tujuan yang telah ditentukan dan ditetapkan oleh perusahaan itulah yang dimaksud motivasi kerja dalam hal ini. Dengan melakasakan program employee relation yang tepat dalam suatu perusahaan dapat membantu perusahaan untuk memiliki kekuatan dalam mengelola suber daya manusia demi mencapai tujuan organisasi. Menurut Sariyuni (2010:141) perilaku seseorang dimulai dengan dorongan tertentu/motivasi. Motivasi yang tinggi dari karyawan sangat berperan penting dan tentu tiap karyawan harus memiliki motivasi, karena dengan tingkat motivasi yang tinggi maka hal tersebut akan membawa perusahaan kearah tujuan yang ingin dicapainya, sebab orang memiliki motivasi tinggi akan terpacu untuk bekerja lebih keras dan penuh semangat karena mereka melihat pekerjaan bukan sekedar sumber penghasilan melainkan untuk mengembangkan diri dan berbakti untuk perusahaan. Dengan demikian,meningkatkan motivasi pada karyawan menjadi hal yang sangat penting yakni dengan melaksanakan program-program yang terdapat pada employee relation tersebut. Namun tetap saja seperti yang telah dikatakan bahwa U Paasha Seminyak dalam 
operasionalnya masih tidak dapat terlepas dari komplain, masih banyak saja ditemukan keluhankeluhan terhadap pelayanan dari karyawan hotel. Keluhan tamu yang terjadi rata-rata akibat berbagai kesalah, dan kelalaian karyawan selama melayani tamu yang menginap. Dengan masih banyak ditemukannya komplain-komplain tamu, sering terjadinya ketidak tepatan waktu penyelesaian pekerjaan oleh karyawan, dan tingginya absensi karyawan hal ini menandakan bahwa terjadinya penurunan motivasi kerja karyawan sehingga menyebabkan produktivitas kerja juga menurun, hal tersebut menunjukan bahwa jika motivasi kerja karyawan menurun maka hal tersebut akan berdampak pada kinerja karyawan dalam memberikan perlayanan kepada tamu mengingat dalam industry perhotelan, selain hospitality maka pelayanan sangat amat penting dalam menunjang keberhasilan suatu perusahaan.

Berdasarkan permasalahan tersebut, diperlukan cara-cara untuk meningkatkan motivasi. Menurut penelitian yang dilakukan oleh Jayanti (2014; dalam Octanisa 2014), untuk meningkatkan motivasi maka dibutuhkan employee relation yang merupakan program hubungan internal yang dapat mempengaruhi motivasi secara positif karena beberapa tujuan dari employee relation adalah menanamkan rasa damai kepada karyawan, menanamkan rasa sukses kepada karyawan, sehingga karyawan akan merasa diberi kesempatan untuk maju dalam mengembangkan kariernya, menanamkan rasa tanggung jawab kepada karyawan, serta yang terpenting yakni menanamkan semangat kerja yang tinggi kepada karyawan.

\section{METODE PENELITIAN}

Penelitian ini dilaksanakan di U Paasha Seminyak, yang berlokasi di Jalan Laksmana No. 77 Seminyak. Hotel U Paasha Seminyak merupakan salah satu 4 stars hotel yang letaknya begitu strategis dan sangat mudah untuk di jumpai karena berada di kawasan Oberoi dan dekat dengan berbagai tempat hiburan terkenal di kawasan Seminyak. Hotel U Paasha Seminyak merupakan bangunan hotel berlantai 5 dengan roof top pool \& bar di lantai teratas serta memiliki fasilitas kamar sebanyak 99 kamar dan juga menyediakan fasilitas dan pelayanan berkelas serta ditunjang dengan berbagai dekorasi dan interior yang mewah di dalamnya. Akses menuju U Paasha Seminyak juga sangat mudah, dapat ditempuh selama 30 menit dari Ngurah Rai International Airport. Dipilihnya lokasi penelitian ini karena lokasinya yang sangat strategis yang berada di kawasan Oberoi dimana dekat dengan tempat-tempat hiburan, dan pusat perbelanjaan seperti Seminyak Village Mall. Dipilihnya U Paasha Seminyak ini sebagai lokasi melakukan penelitian karena merupakan tempat peneliti melaksanakan praktik kerja lapangan yang dimana ditemukannya permasalahan terkait employee relation di dalamnya. Peneliti melihat permasalahan di dalamnya yang dimana masih terdapat keluhan-keluhan tamu yang terjadi pada hotel ini dikarenakan kesalahan dan kelalaian karyawan saat memberikan pelayanan kepada tamu, dan sumber dari hal tersebut yaitu menurunnya motivasi kerja karyawan di U Paasha Seminyak.

Penerapan employee relation di U Paasha Seminyak dilaksanakan melalui programprogram yang terdapat di dalamnya antara lain program pendidikan dan pelatihan pada karyawan, program penghargaan seperti the best employee of the mont, supervisor of the quarter dengan menggunakan leader board, Program acara khusus seperti outing, gathering,charity. Employee communication contohnya seperti penyediaan sarana informasi dan komunikasi serta melaksanakan morning briefing. Employee counseling seperti melakukan brainstrorming dengan karyawan dan bersama-sama mencari jalan keluar atas permasalahan mereka, profit share, seperti pembagian bonus dan insentif, THR, dan hak cuti karyawan, dan juga employee attitude survey. Selain itu dalam hal ini akan dibahas mengenai tingkat partisipasi karyawan dalam setiap kegiatan. Dalam penelitian ini employee relation merupakan variabel bebas yang disimbolkan dengan (X). Employee relation dalam penelitian ini merupakan hubungan internal antar karyawanyang di dalamnya meliputi hubungan komunikasi internal antar sesamakaryawan ataupun hubungan antar karaywan dan manajemen, yang dimana untuk mewujudkan hubungan yang harmonis tersebut pihak manajemen U Paasha seminyak membentuk sebuah program kegiatan yang telah 
dilaksanakan pihak manajemen kepada karyawan U Paasha Seminyak dengan maksud untuk meningkatkan motivasi kerja karyawan.

Teknik pengumpulan data yang digunakan dalam penelitian ini yaitu observasi, yang berarti upaya yang dilakukan oleh pelaksana penelitian kualitatif untuk merekam peristiwa dan kegiatan yang terjadi dengan menggunakan alat bantu maupun tidak (Sugiyono 2016:145), (2) wawancara, dilakukan melalui informan pangkal dan informan kunci sesuai kriteria yang ditentukan. Dalam wawancara ini akan diajukan sejumlah pertanyaan secara lisan atau langsung kepada pihak - pihak yang relevan untuk mendapat informasi yang diperlukan dengan menggunakan alat pedoman wawancara. (3)kuesuioner, suatu metode dengan memberikan daftar pertanyaan kepada responden untuk dijawab. Kuesioner akan dibagikan langsung ke lokasi penelitian kemudian akan diisi oelh karyawan U Paasha Seminyak. (4) Studi kepustakaan yang merupakan teknik pengumpulan data yang dilakukan dengan memperoleh data berupa dokumen, catatan, media, makalah, maupun literature lain yang terkait dengan penelitian ini, dan yang terakhir (5) dokumentasi yang merupakan suatu metode penelitian yang tidak ditujukan langsung kepada subjek penelitian melainkan dengan mengumpulkan data yang meneliti berbagai macam dokumen yang berguna untuk bahan analisis.

Penentuan informan yang digunakan dalam penelitian ini yaitu teknik purposive sampling. Teknik purposive sampling merupakan teknik penentuan informan atau nasumber dengan tujuan tertentu sesuai dengan tema penelitian yang ditetapkan secara sengaja atas dasar kriteria atau pertimbangan tertentu karena orang tersebut dianggap memiliki dan mengetahui informasi yang diperlukan dalam penelitian. Dalam hal ini peneliti memilih informan yang dianggap mengetahui permasalahan yang akan dikaji serta mampu memberikan informasi yang dapat dikembangkan untuk memperoleh data.

Kriteria yang digunakan sebagai dasar atas penentuan informan dalam penelitian ini yaitu : (1) Informan harus mengetahui secara detail mengenai aktivitas-aktivitas yang terdapat dalam program employee relation, (2) Informan harus pernah terjun dan terlibat langsung dalam pengadaan serta pelaksanaan program employee relation.(3) Informan harus mengetahui kondisi dan permasalahan yang terjadi dalam manajemen, terutama terkait pada pelaksanaan program employee relation.Sehingga dalam penelitian ini yang ditetapkan sebagai informan pangkal yaitu Public Relation Manager, sedangkan yang ditetapkan sebagai informan kunci yaitu Human Resource Manager.

Adapun teknik penentuan sampel pada penelitian ini yaitu menggunakan teknik proportional stratified sampling. Proportional stratified sampling merupakan teknik pengambilan pada populasi yang berstrata dengan mengambil sampeldari tiap-tiap sub populasi dengan cara membagi populasi menjadi beberapa sub-sub populasi atau strata (Zainal Arifin, 2012). Arikunto 2006 (dalam Octanisa : 2017-55) memberikan pernyataan bahwa "apabila populasi berjumlah kurang dari 100 maka sebaiknya diambil seluruhnya, dan jika jumlah populasinya banyak atau lebih dari 100 maka dapat diambil 10-15\%, 20-25\%, atau lebih. Dalam penelitian ini sampel yang digunakan yakni sebesar 55\% dari total keseluruhan populasi yakni karyawan yang berjumlah 144 orang sehingga diperoleh hasil 80 untuk jumlah responden dalam penelitian ini.

\section{HASIL DAN PEMBAHASAN}

3.1 Hasil

Berawal dari perusahaan yang bernama Absolute Hotel Service (AHS) yang dibentuk Jonathan dan Kolega serta perusahaan public BTS Holdings. Perusahaan ini menyediakan berbagai layanan unik perhotelan dan konsultasi yang mencakup pemasaramn dan studi kelayakan, lay anan perwakilan, perencanaan konsultasi pre-opening, merk serta jasa pengelolaan hotel dari pelayanan 
dan bantuan pre-opening dengan kontrak manajemen untuk hotel dari resort. Absolute Hotel Service (AHS) merupakan salah satu perusahaan manajemen / branding perhotelan yang paling cepat berkembang di Asia dengan portofolio geografis yang terus berkembang dari hotel resort dan tempat menginap berkelas. AHS memiliki kantor pusat yang berbasis di Bangkok Thailand sedangkan kantor AHS Indochina yang berbasis di Hanoi mencakup Vietnam, Kamboja, dan Laos. Kantor AHS India yang berbasis di Mumbai mencakup India, Maladewa, Nepal, Bangladesh, Mauritus, dan Sri Lanka.

Salah satu brand AHS yang sukses yaitu U Hotel \& Resort, U Hotel \& Resort telah tersebar di berbagai Negaraasia dan Eropa. Dengan U Hotel dan berbeda-beda contohnya seperti U Sathorn Bangkok, U Sapa Hotel Vietnam, dan salah satunya juga tersebar di Bali yaitu U Paasha Seminyak. Pembangunan U Paasha Seminyak dimulai pada tanggal 14 februari 2008 dengan mengerahkan 700 tenaga kerja dan berhasil diselesaikan dalam kurun waktu 3 tahun. Grand opening U Paasha Seminyak pada tanggal 3 Maret 2012, yang di buka secara resmi oleh executive summery AHS yaitu Jinathan Wigley. U Paasha Seminyak pada akhirnya resmi beroperasional secara aktif mulai tanggal 26 April 2012 hingga saat ini.U Paasha Seminyak ini merupakan hotel yang terletak di kawasan Oberoi Seminyak Bali.Berjarak $12 \mathrm{~km}$ dari Bandara Internasional Ngurah Rai atau dapat ditempuh dengan waktu 45 menit perjalanan menggunakan mobil. Sedangkan berjarak $15 \mathrm{~km}$ dari pusat kota (Denpasar) dan dapat ditempuh dengan waktu 25 menit.Bertempat di kawasan pariwisata Seminyak, U Paasha Seminyak menawarkan kemudahan suatu kemudahan akses wisata bagi tamu yang menginap. Karena dalamhotelini tamu akan dimanjakan dengan fasilitas hotel dan beberapa atraksi wisata yang ada di dalamnya.

U Paasha Seminyak memiliki total kamar sebanyak 99 kamar yang terdiri atas 3 tipe kamar dan 1 penthouse, yaitu: Deluxe Rooms, Grande Rooms, Suite rooms. Penhouse merupakan akomodasi yang sangat mewah dengan fasilitas-fasilitas yang bersifat khusus (private). Dengan kamar yang memiliki ricefield view penthouse merupakan tempat yang cocok bagi tamu yang mencari ketengangan dan mengutamakan privasi seperti menginap di villa. U Paasha Seminyak sebagai four stars hotel menyediakan empat restoran dengan berbagai macam hidangan yang disediakan khusus untuk memanjakan tamunya, baik tamu yang menginap maupun tamu yang berkunjung ke U Paasha Seminyak. Setiap restoran memiliki ciri khas dan pelayanan berbeda.

\section{Pelaksanaan Program Employee Relation di U Paasha Seminyak}

Kegiatan / aktivitas dari program employee relation yang merupakan indikator dalam penelitian ini merupakan upaya meningkatkan keterampilan, kinerja karyawan, serta kualitas pelayanan dan jasa maka pihak manajemen mendirikan program pendidikan dan pelatihan ini guna meningkatkan motivasi kerja karyawan. Program pendidikan dan pelatihan ini dilakukan pada tiga lingkup yang berbeda yakni pelatihan yang dilakukan pada tempat kerja, pelatihan yang dilakukan di area Hotel U Paasha Seminyak, serta pendidikan dan pelatihan dalam ruang kelas dengan periode yang berbeda. Untuk program pelatihan pelatihan yang dijalankan dengan periode 1 bulan sekali yakni pelatihan yang dilakukan pada tempat kerja/lingkup kerja karyawan. Kemudian untuk pelatihan dalam ruang kelas dilaksanakan setiap 3 bulan sekali, dalam pendidikan dan pelatihan ini karyawan dari seluruh departemen akan dikumpulkan dalam training room dan akan menyimak sedikit pengetahuan yang bersifat umum, keterampilan khusus, dan kemudian akan karyawan akan mengikuti test tulis. Sedangkan pelatihan yang dilakukan di area U Paasha Seminyak yakni dilakukan dengan periode 6 bulan sekali, pelatihan ini biasanya lebih mengarah kepada pelatihan terkait lingkungan U Paasha Seminyak, pelatihan dan simulasi saat terjadinya bencana, serta pelatihan menangani keadaan darurat seperti kebakaran di lingkungan U Paasha Seminyak.

Program penghargaan merupakan sebuah program yang telah dibentuk oleh perusahaan guna membentuk loyalitas karyawan, baik itu memberikan penghargaan kepada karyawan yang 
memiliki prestasi dengan pencapaian kerja yang maskimal, maupun karyawan dengan masa kerja yang cukup lama. Penerapan program penghargaan di Hotel U Paasha Seminyak ini memiliki periode masing-masing yakni sebulan sekali, tiga bulan sekali, dan satu tahun sekali dan karena program penghargaan ini diperuntukan bagi level supervisor, dan level karyawan biasa/staf, serta karyawan dengan masa kerja dan pengabdian yang lama pada perusahaan. Program penghargaan yang dilaksanakan dengan periode sebulan sekali yakni program penghargaan bagi karyawan terbaik yang disebut sebagai "star of the month" atau yang secara umum familiar dengan sebutan employee of the month dengan memberikan "Thanks Letter" dan memberikannya jatah cuti tambahan. Program penghargaan yang dilaksanakan setiap 3 bulan sekali yakni diperuntukan bagi level supervisor, yang dimana dari seluruh supervisor departemen akan dipilih satu supervisor terbaik yang turut berperan aktif dalam pencapaian tujuan perusahaan yakni "supervisor of the quarter". Supervisor yang telah ditetapkan sebagai supervisor of the quarter akan diberikan penghargaan berupa sertifikat, voucher liburan, serta foto karyawan tersebut akan dipajang pada spot-spot yang telah ditentukan di hotel, serta foto supervisor tersebut akan diletakkan paling atas pada leadershipboard. Pemberian penghargaan kepada karyawan tetap yang telah bekerja selama lebih dari 5 tahun akan diberikan "Long Service Leave Award" yang diberikan kepada seluruh karyawan yang telah memiliki masa kerja selama 5 tahun sehingga dengan begitu karyawan yang sudah cukup lama mendedikasikan dirinya merasa dihargai atas loyalitasnya. Sedangkan untuk bentuk penghargaan yang diberikan kepada karyawan yang berupa promosi kenaikan jabatan, serta kenaikan gaji akan dipertimbangkan dari beberapa segi seperti telah memiliki masa kerja tertentu, dan pencapaian kerjanya selama ini, dan atasan serta pihak manajemen sudah menilai bahwa karyawan yang bersangkutan tersebut memang telah pantas.

Program acara khusus yang telah disusun oleh perusahaan yakni bertujuan untuk melepas rasa penat karyawan dalam bekerja, sekaligus untuk menumbuhkan rasa hangat, kekeluargaan, serta keakraban antar sesama karyawan dari seluruh departemen dan juga atasan. Dalam program ini, terdapat beberapa acara-acara yang dilaksanakan secara rutin dan berkala yang dimana setiap acara dalam program ini memiliki periode tersendiri. dan karyawan sampai atasan juga turut berpartisipasi di dalamnya. Program acara khusus yang rutin dilaksanakan selama satu bulan sekali yakni "Birthday Association. Kemudianprogram outing bersama, merupakan program yang dilaksanakan setiap 6 bulan sekali. Pihak manajemen biasanya akan menentukan lokasi outing beradasarkan keputusan bersama, serta hasil voting dari karyawan dengan suara terbanyak. Program zumba bersama, merupakan program yang dilaksanakan setiap seminggu sekali yakni setiap hari Jumat untuk karyawan seluruh departemen. Program zumba ini dilakukan setiap jam 5 sore hingga pukul 6 sore di ruangan khusus kebugaran di hotel dengan menggunakan istruktur zumba yang telah disediakan khusus dari luar. Selanjutnya U Paasha Seminyak juga memiliki program acara khusus dengan tujuan sebagai peringatan hari raya suci keagamaan, seperti untuk karyawan yang beragama Islam/Muslim pada saat bulan suci Ramadhan menggelar acara berbuka bersama, agama Kristen pada hari raya Natal yang dimana akan digelar peryaan Malam Natal (Christmas Eve), sedangkan peryaan untuk karyawan yang beragama Hindu, pada saat hari raya suci keagamaan akan diadakan sembahyang bersama. Acara Hotel Anniversary, setiap tanggal 25 April yang merupakan hari ulang tahun hotelbiasanya akan diusung tema yang berbeda-beda setiap tahunnya, dan biasanya dapat dilaksanakan di area hotel, maupun diluar hotel (di lokasi lain) tergantung pertimbangan pihak manajemen dan suara terbanyak dari karyawan. Kemudian dalam rangkaian anniversary hotel ini terdapat acara family gathering.

Penerapan program employee communication seperti penyediaan informasi melalui media elektronik yang dimiliki oleh hotel yang dimana informasi-informasi bisa karyawan lihat sendiri pada sebuah televisi khusus (information screen) yang dipasang pada bagian koridor hotel yang dimana pada telivisi tersebut ditampilkan beberapa slides show yang berisikan informasi-informasi terbaru terkait hotel. Selain dengan information screen yang telah disediakan tersebut, biasanya penyampaian infromasi dan komunikasi berjalan melalui "HOD Chat Group" yang dimana dalam grup tersebut komunikasi serta informasi-informasi akan dibagikan oleh masing-masing head of department kepada para karyawannya melalui grup chat per departemen dengan begitu komunikasi, penyampaian, dan penerimaan infromasi dapat berjalan efektif. Selain itu morning briefing bersama dengan pimpinan hotel yang dimana dalam pertemuan tersebut akan dibahas mengenai 
perkembangan hotel, kendala yang terjadi dalam operasional hotel berjalan, solusi yang dapat ditempuh untuk mengatasi kendala, serta dilakukannya penyamaan persepsi antara pihak manajemen dan karyawan sehingga infromasi yang diperoleh menjadi sama dan tidak terdapat lagi informasi serta isu-isu yang simpang siur.

Program konseling ini merupakan sebuah program yang manajemen rancangdalambentuk sebuah strategi yang dimana program ini sendiri dapat memberikan dan membentuk kembali energi positif karyawan karena dengan program konseling ini karyawan diberikan kesempatan untuk dapat mencurahkan segala permasalahan, ketertekanan, rasa gelisah, serta rasa ketidaknyamanannya akan sesuatu hal yang membuat mentalnya terganggu sehingga hal tersebut berdampak pada kinerja yang diberikannya. Program konseling di Hotel U Paasha Seminyak ini diterapkan dengan dua cara yang pertama penerapannya seperti layanan konsultasi yang santai antara HRD dengan karyawan yang bersama-sama mencari akar dari permasalahan yang tengah dihadapi karyawan, serta mencari solusi yang nyaman untuk menyelesaikan permasalahan tersebut. Dengan layanan konsultasi untuk pihak karyawantersebut diharapkan dapat membantunya memenuhi harapannya, serta permasalahan yang tengah dihadapinya dapat terselesaikan. Program konseling beruapa layanan konsultasi ini diadakan pada periode yang tidak ditentukan yang dimana karyawan yang ingin melakukan konsultasi dapat langsung datang. Bentuk penerapan program konseling yang kedua yaitu berupa general staff conseling yang merupakan sebuah program konseling tertulis yang dilaksanakan setiap tiga bulan sekali dan program ini diperuntukan bagi seluruh karyawan yang dimana karyawan tersebut diberikan sebuah formulir untuk diisi. Dalam formulir tersebut karyawan diminta menuliskan apa yang karyawan rasakan, harapan yang karyawan inginkan wujudkan unuk pengembangan kedepannya menuju manajemen yang lebih baik, serta persepsi karyawan terhadap atasan maupun kebijakan hotel.

Program profit share merupakan sebuah program yang paling penting yang diupayakan secara maksimal dalam sebuah perusahaan, karena karyawan merupakan asset penting yang telah membantu hotel untuk mencapai tujuan-tujuannya serta dan karena karyawannya hotel mampu mencapai revenue goals yang telah ditargetkan. Karena karyawan merupakan bagian dari keberhasilaan perkembanganan hotel maka karyawan berhak atas keuntungan yang diperoleh hotel, hal ini wajib diterapkan untuk menjaga tingkat partisipasi karyawan dalam mewujudkan tujuan hotel, dan loyalitas karyawan pada hotel. Profit share yang dimaksudkan dalam penelitian ini yakni pemberian bonus, insentif, serta gaji pokok + service yang sesuai karena service itu sendiri ditentukan oleh seberapa besar revenue yang diperoleh oleh hotel. Selain itu pemberian jaminan kesehatan serta pemberian hak cuti kepada karyawan tetap juga merupakan hal yang sangat penting demi menciptakan rasa sejahtera bagi karyawan.

Program Employee Attitude Survey ini dibuat dengan tujuan untuk mendeteksi adanya reaksi negatif karyawan, serta ketidak nyamanan karyawan terkait kebijakan-kebijakan yang diberlakukan perusahaan. Dari langkah-langkah yang diambil manajemen pada program ini maka pihak manajemen dapat melihat dan mendeteksi reaksi-reaksi karyawan terutama reaksi negatif yang terlihat, serta keinginanan karyawan sehingga melalui survey tersebut pihak manajemen dapat memperoleh data dan informasi serta dapat mengambil langkah yang tepat dan bijak untuk pembinaan selanjutnya agar reaksi negatif dari karyawan tersebut dapat diubah menjadi reaksi positif yang artinya karyawan dapat menerima dengan baik seluruh kebijakan sesuai dengan keinginan sehingga proses kerja dan operasional hotel dapat berjalan dengan baik. Program ini dilaksanakan setiap satu tahun sekali. Hasil yang diperoleh nantinya dapat digunakan sebagai alat bantu untuk membangun program employee relation yang lebih baik lagi kedepannya.

\subsection{Pembahasan}

\section{Pengaruh Employee Relation Terhadap Motivasi Kerja Karyawan}

Dalam penelitian ini data yang telah diperoleh melalui kuesioner yang telah disebarkan kepada karyawan akan dilakukan analisa guna mengetahui persepsi karyawan terhadap variabel dalam penelitian ini yakni variabel employee relation serta variabel motivasi kerja. Dalam hal ini akan dijelaskan terlebih dahulu mengenai karakteristik responden, serta penilaian responden terhadap variable employee relation dan variabel motivasi kerja yang nantinya akan didukung dengan hasil uji instrument seperti uji validitas, uji reliabilitas, uji regresi sederhana, uji korelasi, 
uji determinasi, dan uji hipotesis guna menjawab hipotesis sementara pada penelitian ini dan mengetahui apakah ada pengaruh yang signifikan atas employee relation terhadap motivasi kerja karyawan di Hotel U Paasha Seminyak. Berikut akan dijelaskan terlebih dahulu mengenai karakteristik responden.

\section{Karakteristik Responden}

Dalam penelitian ini karakteristik responden merupakan karakteristik dari karyawan tetap yang bekerja di Hotel U Paasha Seminyak yakni berjumlah 80 orang yang berasal dari 14 departemen yang berbeda. Dari 80 karyawan selaku responden dalam penelitian ini yakni dominan berjenis kelamin laki-laki dengan persentase sebesar 53,75\% yaitu 43 orang, sedangkan responden yang berjenis kelamin perempuan yaitu berjumlah 37 orang dengan persentase $46,25 \%$. Kemudian karakteristik responden berdasarkan kelompok usia, rentang usia 31-35 merupakan usia yang memperoleh nilai tertinggi yakni terdapat 22 orang karyawan selaku responden yang berada pada rentang usia tersebut dengan persentase sebesar $27,5 \%$ hal ini menunjukan bahwa lebih banyak karyawan yang berada pada rentang usia tersebut dan pada usia tersebut merupakan usia yang sedang memiliki produktivitas kerja yang tinggi dengan pengalaman kerja yang matang. Sedangkan rentang usia yang memperoleh nilai terendah yakni rentang usia 21-25 yang dimana terdapat 7 karyawan selaku responden yang berada pada rentang usia tersebut dengan persentase sebesar $8,75 \%$. Selanjutnya untuk karakteristik responden berdasarkan jenjang pendidikannya, yang memperoleh nilai tertinggi adalah S1 dengan nilai sebesar 35\% yaitu terdapat 28 responden hal ini menunjukan bahwa kebanyakan dari karyawan sadar akan pentingnya pendidikan, dan untuk dapat bekerja dengan baik pada level manajemensetidaknya karyawan telah berada pada jenjang pendidikan S1 ataupun Diploma IV, sedangkan jenjang pendidikan yang memperoleh nilai paling rendah yaitu jenjang pendidikan $\mathrm{S} 2$ terdapat sebanyak 5 orang responden dengan persentase $6,25 \%$ dari 80 orang responden dalam penelitian ini hal ini menunjukan bahwa S2 merupakan jenjang pendidikan yang masih minim dimiliki karyawan karena yang memiliki jenjang pendidikan S2 tersebut merupakan director dan beberapa manager departemen di U Paasha Seminyak.

Dalam penelitian ini, faktor agama juga penting untuk diketahui dan menjadi salah satu karakteristik responden pada penelitian ini dikarenakan atas beberapa pertimbangan berikut: keberagamaan agama yang dianut oleh karyawan sehingga tentu diperlukannya sebuah koordinasi untuk libur Hari Raya (Public Holiday) untuk masing-masing agama, kemudian disamping itu untuk menciptakan lingkungan kerja yang kondusif walaupun agama karyawan yang beragam. Dari 80 karyawan selaku responden dalam penelitian ini yakni dominan beragama Hindu yaitu sebanyak 37 orang dengan tingkat persentase sebesar $46,25 \%$ hal ini dikarenakan karyawan yang bekerja di U Paasha Seminyak dominan beragama Hindu dan sebagian besar karyawan yang bekerja berasal dari Bali yang dimana Bali sendiri mayoritas beragama Hindu. Sedangkan agama yang memperoleh nilai terendah yakni Budha tedapat 1 responden dengan persentase sebesar $1,25 \%$. Kategori selanjutnya yakni karakteristik responden berdasarkan jabatan, dalam penelitian ini jabatan responden yang mendominasi yaitu staf sebanyak 59 orang dengan tingkat persentase 73,75\% hal ini menunjukan karena memang lebih banyak karyawan yang bekerja pada level staf dan juga lebih banyak reponden dengan jabatan staf yang berkenan mengisi kuesioner penelitian ini. Sedangkannilai terendah terdapat hanya 1 responden yang menjabat sebagai director yaitu dengan tingkat persentase $1,25 \%$ hal ini dikarenakan level director memang tidak dapat ditemui secara sembarang mengingat level director merupakan level untuk orang-orang pemimpin perusahaan.Kemudian kategori terakhir yaitu terkait masa bekerja responden sebagian besar responden telah bekerja selama 7 tahun yang dimana terdapat sebanyak 32 orang responden dengan tingkat persentase sebesar $40 \%$ hal ini menunjukan bahwa banyak karyawan yang loyal dan telah bekerja selama 7 tahun karena Hotel U Paasha Seminyak ini sendiri sudah berdiri selama 7 tahun hingga saat ini. Dan nilai paling terendah yaitu masa kerja selama 1-2 tahun yaitu dengan tingkat persentase $6,25 \%$ dengan jumlah 5 responden.

\section{Uji Validitas}

Uji validitas dalam penelitian ini yakni digunakan untuk mengetahui sah atau valid tidaknya suatu kuesioner. Suatu kuesioner bisa dikatakan valid jika pertanyaan pada kuesioner 
mampu untuk mengungapkan sesuatu yang akan diukur oleh kuesioner tersebut. Dengan uji validitas, maka akan dilakukan dengan cara membandingkan nilai $r$ hitung dengan nilai $r$ tabel. Jika pada tingkat signifikan 5\% nilai $r$ hitung $>0,30$ maka dapat disimpulkan bahwa butir instrumen tersebut valid. Pengujian validitas dapat dilakukan dengan software SPSS 24 for windows.

Tabel 7.RekapitulasiHasil Uji Validitas Instrumen Penelitian

\begin{tabular}{|c|c|c|c|c|}
\hline Variabel & Indikator & Koefisien Korelasi & Korelasi Batas & Keterangan \\
\hline \multirow{14}{*}{$\begin{array}{c}\text { Employee } \\
\text { Relation }(\mathrm{X})\end{array}$} & $\mathrm{X}_{1}$ & 0,529 & 0,30 & Valid \\
\hline & $\mathrm{X}_{2}$ & 0,506 & 0,30 & Valid \\
\hline & $\overline{X_{3}}$ & 0,726 & 0,30 & Valid \\
\hline & $\mathrm{X}_{4}$ & 0,511 & 0,30 & Valid \\
\hline & $\mathrm{X}_{5}$ & 0,639 & 0,30 & Valid \\
\hline & $\mathrm{X}_{6}$ & 0,599 & 0,30 & Valid \\
\hline & $\mathrm{X}_{7}$ & 0,668 & 0,30 & Valid \\
\hline & $\mathrm{X}_{8}$ & 0,657 & 0,30 & Valid \\
\hline & $\overline{X_{9}}$ & 0,637 & 0,30 & Valid \\
\hline & $\mathrm{X}_{10}$ & 0,673 & 0,30 & Valid \\
\hline & $\mathrm{X}_{11}$ & 0,702 & 0,30 & Valid \\
\hline & $\mathrm{X}_{12}$ & 0,684 & 0,30 & Valid \\
\hline & $\mathrm{X}_{13}$ & 0,751 & 0,30 & Valid \\
\hline & $\mathrm{X}_{14}$ & 0,718 & 0,30 & Valid \\
\hline \multirow{10}{*}{$\begin{array}{l}\text { Motivasi kerja } \\
\text { karyawan }(\mathrm{Y})\end{array}$} & $\mathrm{Y}_{.1}$ & 0,552 & 0,30 & Valid \\
\hline & $\mathrm{Y}_{.2}$ & 0,629 & 0,30 & Valid \\
\hline & $\mathrm{Y}_{.3}$ & 0,541 & 0,30 & Valid \\
\hline & $\mathrm{Y}_{.4}$ & 0,567 & 0,30 & Valid \\
\hline & $\mathrm{Y}_{.5}$ & 0,628 & 0,30 & Valid \\
\hline & $Y_{.6}$ & 0,684 & 0,30 & Valid \\
\hline & $\mathrm{Y}_{.7}$ & 0,663 & 0,30 & Valid \\
\hline & $\mathrm{Y}_{.8}$ & 0,668 & 0,30 & Valid \\
\hline & $\mathrm{Y}_{.9}$ & 0,642 & 0,30 & Valid \\
\hline & $\mathrm{Y}_{.10}$ & 0,717 & 0,30 & Valid \\
\hline
\end{tabular}




\begin{tabular}{|c|c|c|c|c|}
\hline & Y.11 & 0,570 & 0,30 & Valid \\
\cline { 2 - 5 } & $Y_{.12}$ & 0,629 & 0,30 & Valid \\
\hline
\end{tabular}

Sumber: Data primerdiolah (2019)

Hasil uji validitas pada tabel 7.menunjukkan bahwa seluruh instrumen penelitian yang digunakan untuk mengukur variabel employee relationdan motivasi kerja karyawan memiliki nilai koefisien korelasi dengan skor total seluruh item pernyataan lebih besar dari 0,30 . Hal ini menunjukkan bahwa butir-butir pernyataan dalam instrument penelitian tersebut valid dan layak digunakan sebagai instrument penelitian.

\section{Uji Reliabilitas}

Uji reliabilitas adalah pengujian yang dilakukan untuk mengetahui sejauh mana pengukuran tersebut menjamin pengukuran yang konsisten. Reliabilitas merupakan data untuk mengukur suatu kuesioner yang merupakan indikator dari variable atau konstruk. Suatu kuesioner dikatakan atau handal jika jawaban seseorang terhadap pertanyaan adalah konsisten atau stabil dari waktu ke waktu. Suatu variable dikatakan reliabel jika memberikan nilai Cronbach Alpa $(\alpha)>0,60$ dan begitupun juga berlaku sebaliknya.

Tabel 8.Rekapitulasi HasilUji Reliabilitas Instrumen Penelitian

\begin{tabular}{|c|l|c|c|}
\hline No. & \multicolumn{1}{|c|}{ Variabel } & Cronbach's Alpha & Keterangan \\
\hline $\mathbf{1}$ & Employeerelation $(\mathrm{X})$ & 0,890 & Reliabel \\
\hline $\mathbf{2}$ & Motivasi kerja karyawan $(\mathrm{Y})$ & 0,850 & Reliabel \\
\hline
\end{tabular}

Sumber: Data primer diolah(2019)

Hasil uji reliabilitas yang disajikan dalam Tabel 8. menunjukkan bahwa seluruh instrumen penelitian memiliki koefisien Cronbach's Alpha lebih dari 0,60. Jadi dapat dinyatakan bahwa seluruh variabel telah memenuhi syarat reliabilitas atau kehandalan sehingga dapat digunakan untuk melakukan penelitian.

\section{Analisis Deskripsi Jawaban Responden}

Pengumpulan data melalui kuesioner terdiri atas pernyataan responden berdasarkan masing-masing variabel, yaitu: employee relation dan Motivasi kerja karyawan. Penilaian responden mengenai variabel-variabel dalam penelitian perlu dilakukan penentuan distribusi frekuensi berdasarkan nilai intervalnya, adapun untuk menentukan nilai interval yang dimaksud adalah sebagai berikut.

Skor pada penelitian ini memiliki nilai tertinggi maksimal 4 dan terendah minimal 1 , sehingga dapat disusun kriteria pengukuran sebagai berikut.

Tabe19. Kriteria Pengukuran Deskripsi Varia bel Penelitian

\begin{tabular}{|l|l|l|}
\hline No. & \multicolumn{1}{|c|}{ Skala Pengukuran } & \multicolumn{1}{c|}{ Kategori } \\
\hline 1 & $1,00-1,75$ & SangatTidak Setuju \\
\hline 2 & $1,76-2,51$ & Tidak Setuju \\
\hline 3 & $2,52-3,27$ & Sejutu \\
\hline 4 & $3,28-4,00$ & SangatSetuju \\
\hline
\end{tabular}

Sumber: Ghozali(2016) 


\section{Deskripsi Responden terhadap Employee Relation}

Variabel employee relation dalam penelitian ini merupakan variabel bebas yang diukur dengan menggunakan 14 pernyataan yang berhubungan dengan employee relation. Secara rinci hasil penelitian mengenai jawaban responden terhadap variabel employee relation dapat dilihat pada Tabel 10 berikut.

Tabel 10. Deskripsi Ja waban Responden Terhadap Employee Relation

\begin{tabular}{|c|c|c|c|c|c|c|c|}
\hline \multirow[t]{2}{*}{ No } & \multirow[t]{2}{*}{ Pernyataan } & \multicolumn{4}{|c|}{$\begin{array}{c}\text { Frekuensi Jawaban } \\
\text { Responden }\end{array}$} & \multirow[t]{2}{*}{$\begin{array}{l}\text { Rata- } \\
\text { Rata }\end{array}$} & \multirow[t]{2}{*}{ Kategori } \\
\hline & & $\begin{array}{l}\text { STS } \\
\text { (1) }\end{array}$ & $\begin{array}{l}\text { TS } \\
\text { (2) }\end{array}$ & $\begin{array}{l}\mathrm{S} \\
\text { (3) }\end{array}$ & $\begin{array}{l}\text { SS } \\
\text { (4) }\end{array}$ & & \\
\hline \multicolumn{8}{|c|}{ Program Pendidikan dan Pelatihan } \\
\hline 1 & $\begin{array}{l}\text { Pemberian program pelatihan } \\
\text { dapat meningkatkan keterampilan } \\
\text { kerja karyawan. }\end{array}$ & 0 & 0 & 48 & 32 & 3,40 & SangatSetuju \\
\hline 2 & $\begin{array}{l}\text { Pemberian program pelatihan } \\
\text { dapat meningkatkan kualitas jasa } \\
\text { pelay anan yang diberikan. }\end{array}$ & 0 & 0 & 57 & 23 & 3,29 & SangatSetuju \\
\hline \multicolumn{6}{|c|}{ Rata-Rata } & 3,34 & SangatSetuju \\
\hline \multicolumn{8}{|c|}{ Program Penghargaan } \\
\hline 3 & $\begin{array}{l}\text { Pemberian penghargaan kepada } \\
\text { karyawan terbaik dapat } \\
\text { meningkatkan ra sa dihargai. }\end{array}$ & 0 & 1 & 50 & 29 & 3,35 & SangatSetuju \\
\hline 4 & $\begin{array}{l}\text { Pemberian penghargaan kepada } \\
\text { karyawan berdasarkan hasil test } \\
\text { dapat meningkatkan motivasi } \\
\text { kerja serta menambah } \\
\text { pengetahuan karyawan dalam } \\
\text { pekerjaannya. }\end{array}$ & 0 & 4 & 59 & 17 & 3,16 & Setuju \\
\hline \multicolumn{6}{|c|}{ Rata-Rata } & 3,25 & Setuju \\
\hline \multicolumn{8}{|c|}{ Program Acara Khusus } \\
\hline 5 & $\begin{array}{l}\text { Kegiatan outing dan gathering } \\
\text { dapat membangun hubungan baik } \\
\text { antara karyawan. }\end{array}$ & 0 & 1 & 54 & 25 & 3,30 & SangatSetuju \\
\hline 6 & $\begin{array}{l}\text { Melakukan kegiatan sosial } \\
\text { bersa ma dapat menumbuhkan } \\
\text { ra sa kebersamaan. }\end{array}$ & 0 & 1 & 57 & 22 & 3,26 & Setuju \\
\hline \multicolumn{6}{|c|}{ Rata-Rata } & 3,28 & Sangat Setuju \\
\hline \multicolumn{8}{|c|}{ Employee Communication Program } \\
\hline 7 & $\begin{array}{l}\text { Penyediaan sarana informasidan } \\
\text { komunikasi berupa media } \\
\text { elektronik dapat menyampaikan } \\
\text { keluhan atau saran secara efektif. }\end{array}$ & 0 & 2 & 62 & 16 & 3,17 & Setuju \\
\hline
\end{tabular}




\begin{tabular}{|c|c|c|c|c|c|c|c|}
\hline 8 & $\begin{array}{l}\text { Morning briefing yang rutin } \\
\text { untuk karyawan dapat } \\
\text { membangun komunikasi intens } \\
\text { dua arah yang baik saat bekerja. }\end{array}$ & 0 & 3 & 60 & 17 & 3,17 & Setuju \\
\hline \multicolumn{6}{|c|}{ Rata-Rata } & 3,17 & Setuju \\
\hline 9 & $\begin{array}{l}\text { Program konseling untuk pihak } \\
\text { karyawan dapat membantu dalam } \\
\text { memenuhi ha rapan karyawan. }\end{array}$ & 0 & 3 & 59 & 18 & 3,19 & Setuju \\
\hline 10 & $\begin{array}{l}\text { Program konselingdapat } \\
\text { membantu karyawan dalam } \\
\text { mencari solusia tas masalah yang } \\
\text { dimiliki oleh karyawan. }\end{array}$ & 0 & 5 & 67 & 8 & 3,04 & Setuju \\
\hline \multicolumn{6}{|c|}{ Rata-Rata } & 3,12 & Setuju \\
\hline \multicolumn{8}{|c|}{ ProfitShare } \\
\hline 11 & $\begin{array}{l}\text { Pemberian bonus, insentif, serta } \\
\text { gajiyang sesuai membantu } \\
\text { meningkatkan motivasi kerja } \\
\text { yang maksimal. }\end{array}$ & 0 & 8 & 45 & 27 & 3,24 & Setuju \\
\hline 12 & $\begin{array}{l}\text { Pemberian hak cuti dan jaminan } \\
\text { kesehatan a kan meningkatkan } \\
\text { rasa kesejateraan karyawan. }\end{array}$ & 0 & 8 & 50 & 22 & 3,17 & Setuju \\
\hline \multicolumn{6}{|c|}{ Rata-Rata } & 3,21 & Setuju \\
\hline \multicolumn{8}{|c|}{ Employee's Attitude Survey } \\
\hline 13 & $\begin{array}{l}\text { Penilaian oleh pihak manajemen } \\
\text { kepada karyawannya dapat } \\
\text { menin gkatkan kinerja dan } \\
\text { motivasi kerja karyawan. }\end{array}$ & 0 & 21 & 47 & 12 & 2,89 & Setuju \\
\hline 14 & $\begin{array}{l}\text { Penilaian sikap, kinerja, dan } \\
\text { loya litas karyawan dapat } \\
\text { memberikan data dan informasi } \\
\text { untuk pembinaan selanjutnya }\end{array}$ & 0 & 20 & 41 & 19 & 2,99 & Setuju \\
\hline \multicolumn{6}{|c|}{ Rata-Rata } & 2,94 & Setuju \\
\hline \multicolumn{6}{|c|}{ Rata-rata keseluruhan variabelfaktor Employee Relation } & 3,19 & Setuju \\
\hline
\end{tabular}

Sumber: Data Diolah (2019)

Tabel 10 menunjukkan employee relation secara keseluruhan setuju hal ini dapat dilihat dari keseluruhan rata-rata nilai employee relation yaitu 3,19 yang dimana rata-rata dari tanggapan karyawan berada dalam kategori setuju jadi tersebut menunjukan bahwa employee relation di $\mathrm{U}$ Paasha Seminyak dapat diterima serta diterapkan dan dilaksanakan dengan baik.

Jika dilihat pada tabel 4.10 dari ke 7 indikatoremployee relation, indikator yang memiliki nilai rata-rata tertinggi yaitu terdapat pada indikator program pendidikan dan pelatihan yaitu dengan total rata-rata sebesar 3,34 dan hal tersebut dikarenakan karyawan sendiri telah merasakan pengaruh positif dari program pendidikan dan pelatihan yang telah berjalan dengan sangat baik di U Paasha Seminyak. Sedangkan indikator dengan nilai rata-rata terendah ditemukan pada indikator employee's attitude survey dengan total rata-rata sebesar 2,94 namun masih termasuk dalam kategori setuju, hal tersebut menunjukan terjadinya perbedaan pendapat pada responden terkait 
program ini karena pada program ini yang memiliki 2 sub indikator di dalamnya masih ditemukan jawaban tidak setuju dengan jumlah yang lumayan banyak yaitu dengan total nilai sebanyak 40 .

\section{Deskripsi Motivasi kerja karyawan}

Variabel motivasi kerja karyawan dalam penelitian ini merupakan variabel bebas yang diukur dengan menggunakan 11 pernyataan yang berhubungan dengan motivasi kerja karyawan. Secara rinci hasil penelitian mengenai jawaban responden terhadap variabel motivasi kerja karyawan dapat dilihat pada Tabel 11 berikut.

Tabel 11. Deskripsi Ja waban Responden Terhadap Motivasi Kerja Karyawan

\begin{tabular}{|c|c|c|c|c|c|c|c|}
\hline \multirow[t]{2}{*}{ No } & \multirow[t]{2}{*}{ Pernyataan } & \multicolumn{4}{|c|}{$\begin{array}{c}\text { Frekuensi Jawaban } \\
\text { Responden }\end{array}$} & \multirow[t]{2}{*}{$\begin{array}{l}\text { Rata- } \\
\text { Rata }\end{array}$} & \multirow[t]{2}{*}{ Kategori } \\
\hline & & $\begin{array}{l}\text { STS } \\
\text { (1) }\end{array}$ & $\begin{array}{l}\text { TS } \\
\text { (2) }\end{array}$ & $\begin{array}{l}\mathrm{S} \\
(3)\end{array}$ & $\begin{array}{l}\text { SS } \\
\text { (4) }\end{array}$ & & \\
\hline \multicolumn{8}{|c|}{ Semangat Kerja } \\
\hline 1 & $\begin{array}{l}\text { Semangatkerja mampu } \\
\text { mempengaruhi produktivitas } \\
\text { kerja karyawan. }\end{array}$ & 0 & 2 & 32 & 46 & 3,55 & SangatSetuju \\
\hline 2 & $\begin{array}{l}\text { Semangat kerja yang tinggi } \\
\text { dapat mendorong karyawan } \\
\text { dalam mencapai tujuan. }\end{array}$ & 0 & 3 & 29 & 48 & 3,56 & SangatSetuju \\
\hline \multicolumn{6}{|c|}{ Rata - Rata } & 3,55 & Sangat Setuju \\
\hline \multicolumn{8}{|c|}{ Inisiatif dan Kreativitas } \\
\hline 3 & $\begin{array}{l}\text { Inisia tif dalam bekerja dapat } \\
\text { menciptakan semangat kerja. }\end{array}$ & 0 & 3 & 43 & 34 & 3,39 & SangatSetuju \\
\hline 4 & $\begin{array}{l}\text { Kreativitas dalam bekerja dapat } \\
\text { meningkatkan produktivitas. }\end{array}$ & 0 & 3 & 40 & 37 & 3,43 & SangatSetuju \\
\hline \multicolumn{6}{|c|}{ Rata-Rata } & 3,41 & Sangat Setuju \\
\hline \multicolumn{8}{|c|}{ Rasa Tanggung Jawab } \\
\hline 5 & $\begin{array}{l}\text { Dengan memiliki rasa tanggung } \\
\text { ja wab dapat menyelesaikan } \\
\text { tugas dengan benar sesuai } \\
\text { dengan prosedur } \\
\end{array}$ & 0 & 4 & 48 & 28 & 3,30 & SangatSetuju \\
\hline 6 & $\begin{array}{l}\text { Dengan memiliki rasa tanggung } \\
\text { ja wabdapat menyelesaikan } \\
\text { tugas secara tepat waktu }\end{array}$ & 0 & 5 & 63 & 12 & 3,09 & Setuju \\
\hline \multicolumn{6}{|c|}{ Rata-Rata } & 3,20 & Setuju \\
\hline \multicolumn{8}{|c|}{ Disiplin Kerja } \\
\hline 7 & $\begin{array}{l}\text { Disiplin dalam absensiakan } \\
\text { membatu efesiensi kerja } \\
\text { karyawan. }\end{array}$ & 0 & 6 & 64 & 10 & 3,05 & Setuju \\
\hline 8 & $\begin{array}{l}\text { Displin akan SOP dalambekerja } \\
\text { mengurangi kesalahan kerja } \\
\text { yang menyebabkan terjadinya } \\
\text { komplain. }\end{array}$ & 0 & 4 & 44 & 32 & 3,35 & SangatSetuju \\
\hline
\end{tabular}




\begin{tabular}{|c|c|c|c|c|c|c|c|}
\hline \multicolumn{6}{|c|}{ Rata-Rata } & $\mathbf{3 , 2 0}$ & Setuju \\
\hline \multicolumn{8}{|c|}{ Loyalitas Kerja } \\
\hline 9 & $\begin{array}{l}\text { Kemauan untuk melakukan } \\
\text { suatu pekerjaan karena dorongan } \\
\text { daridiri karyawan sendiri dapat } \\
\text { menyelesaikan tugas tepat } \\
\text { waktu. }\end{array}$ & 0 & 5 & 59 & 16 & 3,14 & Setuju \\
\hline 10 & $\begin{array}{l}\text { Kerelaan dalam melakukan } \\
\text { usaha yang besar dapat } \\
\text { membantu dalam pencapaian } \\
\text { tujuan perusahaan. }\end{array}$ & 0 & 6 & 68 & 6 & 3,00 & Setuju \\
\hline \multicolumn{6}{|c|}{ Rata-Rata } & 3,07 & Setuju \\
\hline \multicolumn{8}{|c|}{ Memperhatikan Kesempatan untuk Maju } \\
\hline 11 & $\begin{array}{l}\text { Promosi jabatan dapat } \\
\text { meningkatkan semangat } \\
\text { karyawan dalammemberikan } \\
\text { kinerja nya secara maksimal. }\end{array}$ & 0 & 8 & 37 & 35 & 3,34 & SangatSetuju \\
\hline 12 & $\begin{array}{l}\text { Program employee exchange to } \\
\text { international chain dapat } \\
\text { meningkatkan semangat dan } \\
\text { motivasi karyawan dalam } \\
\text { bekerja. }\end{array}$ & 0 & 7 & 47 & 26 & 3,24 & Setuju \\
\hline \multicolumn{6}{|c|}{ Rata-Rata } & 3,29 & Setuju \\
\hline \multicolumn{6}{|c|}{ Rata-rata keseluruhan variabelfaktor Motivasi kerja karyawan } & 3,29 & Sangat Setuju \\
\hline
\end{tabular}

Sumber: Data Primer Diolah (2019)

Tabel 11 menunjukkan bahwa motivasi kerja yang terdiri dari 6 indikator karyawan secara keseluruhan responden dalam penelitian ini memberikan pendapat sangat setuju hal ini dapat dilihat dari keseluruhan rata-rata nilai motivasi kerja karyawan yaitu 3,29. Jika dilihat pada tabel 11 dari ke 6 indikator motivasi kerja, indikator yang memiliki nilai rata-rata tertinggi yaitu terdapat pada indikator semangat kerja yaitu dengan total rata-rata sebesar 3,55 dan hal tersebut dikarenakan karyawan sebagian besarmemberikan pendapat yang tinggi terhadap penyataan tersebut bahwa motivasi untuk mencapai tujuan dan produktivitas kerja secara maksimal melainkan adalah memiliki semangat kerja yang baik.

\section{Analis Regresi Linier Sederhana}

Analisis regresi linier sederhana digunakan untuk mengetahui ketergantungan antara satu variable bebas dengan satu variable terikat untuk menduga arah dari hubungan tersebut serta mengukur derajat keeratan hubungan atara satu variable bebas dengan satu variable terikat. Adapun persamaan regresi dalam penelitian ini untuk menganalisis motivasi kerja karyawan sebagai variabel dependen (Y) dengan Employee relation (X) sebagai variabel independen. 
Tabel 12. Hasil Ana lisis Regresi Linier Sederhana

\begin{tabular}{|c|c|c|c|c|c|c|}
\hline \multicolumn{7}{|c|}{ Coefficients $^{\mathrm{a}}$} \\
\hline & \multirow[t]{2}{*}{ Model } & \multicolumn{2}{|c|}{$\begin{array}{l}\text { Unstandardized } \\
\text { Coefficients }\end{array}$} & $\begin{array}{l}\text { Standardized } \\
\text { Coefficients }\end{array}$ & \multirow[t]{2}{*}{$\mathrm{T}$} & \multirow[t]{2}{*}{ Sig. } \\
\hline & & B & Std. Error & Beta & & \\
\hline \multirow[t]{2}{*}{1} & (Constant) & 11.470 & 2.890 & & 3.969 & .000 \\
\hline & $\begin{array}{c}\text { Employee } \\
\text { Relation }\end{array}$ & .626 & .064 & .740 & 9.726 & .000 \\
\hline & & ivasi K & & & & \\
\hline
\end{tabular}

Sumber: Data primer diolah(2019)

Berdasarkan Tabel 12 dapat dibuat persamaan regresi linier sederhana berikut:

$Y=11,470+0,626 X$

1. Konstanta $(\alpha)$ sebesar 11,470 memiliki arti apabila employee relationmemiliki nilai konstan pada angka nol maka nilai motivasi kerja karyawan akan bernilai sebesar 11,470.

2. Koefisien regresi variabel employee relation sebesar 0,626 bernilai positif memiliki arti apabila kualitas layananbernilai 1 satuan maka motivasi kerja karyawan juga akan semakin meningkat sebesar 0,626 dengan asumsi variabel lainnya konstan pada angka nol.

\subsubsection{Analisis Korelasi}

Uji korelasi digunakan untuk mengetahui hubungan yang postif atau signifikan atau sebaliknya antara variable $\mathrm{X}$ dan $\mathrm{Y}$. Teknik analisis yang digunakan adalah analisis product moment dengan angka kasar. Dibawah ini merupakan rumus untuk uji korelasi tersebut. Dalam penelitian ini uji korelasi akan dilakukan dengan menggunakan SPSS 24 for windows.

Tabel13. Hasil Ujit-test

\begin{tabular}{|c|c|c|c|c|c|c|c|c|c|}
\hline \multicolumn{10}{|c|}{ Model Summary } \\
\hline \multirow{2}{*}{$\begin{array}{l}\text { Mo } \\
\text { del }\end{array}$} & \multirow[t]{2}{*}{$\mathrm{R}$} & \multirow{2}{*}{$\begin{array}{l}\text { R } \\
\text { Squar } \\
\text { e }\end{array}$} & \multirow{2}{*}{$\begin{array}{l}\text { Adjus } \\
\text { ted R } \\
\text { Squar } \\
\text { e }\end{array}$} & \multirow{2}{*}{$\begin{array}{l}\text { Std. } \\
\text { Error of } \\
\text { the } \\
\text { Estimate }\end{array}$} & \multicolumn{5}{|c|}{ Change Statistics } \\
\hline & & & & & $\begin{array}{l}\text { R Square } \\
\text { Change }\end{array}$ & F Change & $\begin{array}{l}\mathrm{df} \\
1\end{array}$ & df 2 & $\begin{array}{l}\text { Sig. F } \\
\text { Change }\end{array}$ \\
\hline 1 & $.740^{\mathrm{a}}$ & .548 & .542 & 2.695 & .548 & 94.600 & 1 & 78 & .000 \\
\hline \multicolumn{10}{|c|}{ a. Predictors: (Constant), Employee Relation } \\
\hline
\end{tabular}

Sumber: Da ta primer diolah(2019)

Berdasarkan hasil analisis korelasi Tabel 13, employee relation terhadap motivasi kerja karyawan memiliki nilai korelasi sebesar 0,740 bernilai positif. Hasil ini mempunyai arti bahwa employee relation dan motivasi kerja karyawan memiliki korelasi yang positif dan kuat. 


\section{Uji T (Parsial)}

Uji hipotesis untuk analisis regresi linier sederhana ini menggunakan uji t yang menunjukan seberapa jauh pengaruh satu variabel independen X (Employee Relation) terhadap variabel dependen Y (Motivasi Kerja) (Utama,2016). Uji t dilakukan untuk menguji hipotesis bahwa ada pengaruh signifikan antara variabel employee relation terhadap motivasi kerja karyawan dengan menggunakan bantuan SPSS versi 24 for windows. Jika probabilitas nilai t atau signifikansi $<0,05$, maka dapat dikatakan bahwa terdapat pengaruh antara variabel bebas terhadap variabel terikat secara parsial. Namun, jika probabilitas nilai t atau signifikansi $>0,05$, maka dapat dikatakan bahwa tidak terdapat pengaruh yang signifikan antara masing-masing variabel bebas terhadap variabel terikat.

Tabel 14. Hasil Ujit-test

\begin{tabular}{|c|c|c|c|c|c|c|}
\hline \multicolumn{7}{|c|}{ Coefficients $^{\mathrm{a}}$} \\
\hline \multirow{2}{*}{\multicolumn{2}{|c|}{ Model }} & \multicolumn{2}{|c|}{$\begin{array}{l}\text { Unstandardized } \\
\text { Coefficients }\end{array}$} & $\begin{array}{l}\text { Standardized } \\
\text { Coefficients }\end{array}$ & \multirow[t]{2}{*}{$\mathrm{t}$} & \multirow[t]{2}{*}{ Sig. } \\
\hline & & B & $\begin{array}{l}\text { Std. } \\
\text { Error }\end{array}$ & Beta & & \\
\hline \multirow[t]{2}{*}{1} & (Constant) & 11.470 & 2.890 & & 3.969 & .000 \\
\hline & $\begin{array}{l}\text { Employee } \\
\text { Retention }\end{array}$ & .626 & .064 & .740 & 9.726 & .000 \\
\hline & dent Varial & otivasi K & & & & \\
\hline
\end{tabular}

Sumber: Data primerdiolah(2019)

Untuk menguji $\mathrm{H}_{0}$ diterima atau ditolak digunakan langkah-langkah sebagai berikut:

1. Menentukan formulasi hipotesis

Ho $: \beta \leq 0, \quad$ Tidak ada pengaruh positif antara employee relationterhadap motivasi kerja karyawan di U Paasha Seminyak.

Ha $: \beta>0, \quad$ Ada pengaruh positif antara employee relationterhadap motivasi kerja karyawan diU Paasha Seminyak.

2. Penentuan Statistik Tabel

a. Tingkat Kesalahan $(\alpha)$ sebesar $5 \%=0,05$

b. Derajat kebebasan $(\mathrm{dk})=\mathrm{N}-\mathrm{k}$, diperoleh nilai $\mathrm{t}$-tabel $(0,05 ; \mathrm{N}-\mathrm{k})=(80-2=78)$, maka t tabel $=1,991$

3. Kriteria Pengujian

a. Jika t-hitung <1,991 maka Ho diterima berarti pengaruh tidak signifikan.

b. Jika t-hitung $>1,991$ maka Ho ditolak berarti pengaruh signifikan.

4. Membandingkan $t$ hitung dengan $t$ tabel

Nilai t hitung > t tabel $(9,726>1,991)$ maka Ho ditolak dan $\mathrm{H}_{1}$ diterima.Untuk lebih jelasnya, dapat dilihat pada kurva normal di bawah ini. 


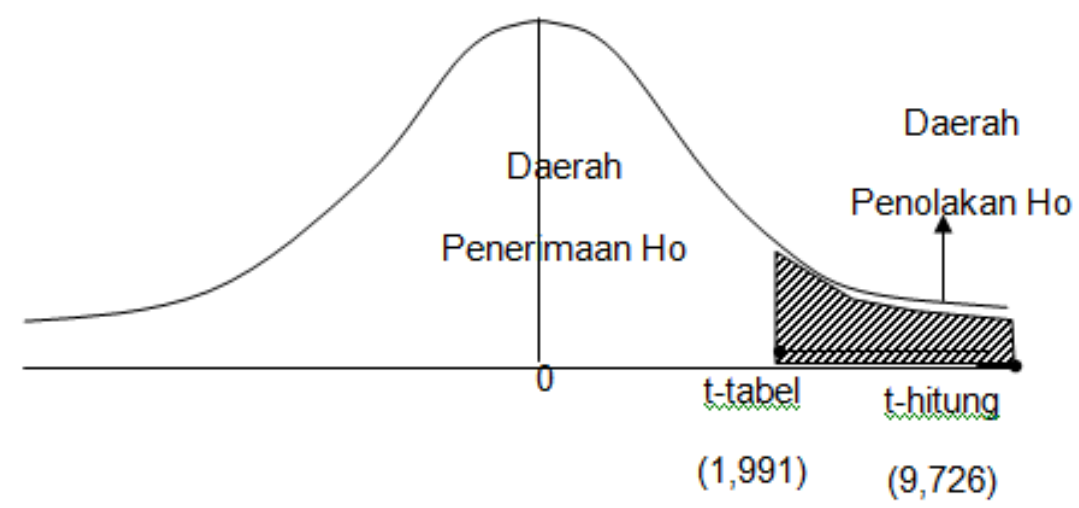

Gambar 2 : Daerah Penerimaan Dan Penolakan Ho (T T $_{1}$-Test $)$

Berdasarkan hasil analisis pengaruh employee relation terhadap motivasi kerja karyawandiperoleh nilai signifikansi sebesar 0,000 kurang dari $0,05(0,000<0,05)$ dengan nilai koefisien regresi sebesar 0,626 bernilai positif dan nilai $\mathrm{t}$ hitung lebih besar dibandingkan $\mathrm{t}$ tabel (9,726>1,991). Hasil ini mempunyai arti bahwa Ada pengaruh positif antara employee relationterhadap motivasi kerja karyawan diU Paasha Seminyak.

\section{Analisis Determinasi}

Analisis koefisien determinasi digunakan untuk melihat seberapa persentase (\%) besarnya pengaruh variabel $\mathrm{X}$ terhadap $\mathrm{Y}$, biasanya dinyatakan dengan persentase. Adapun hasil analisis koefisien determinasi besar kontribusi (\%)antara employee relation terhadap Motivasi kerja karyawan sebagai berikut.

Tabel 15. Hasil Analisis Koefisien Determinasi

\begin{tabular}{|l|c|r|r|r|}
\hline \multicolumn{5}{|c|}{ Model Summary } \\
\hline Model & $\mathrm{R}$ & $\mathrm{R}$ Square & $\begin{array}{c}\text { Adjusted R } \\
\text { Square }\end{array}$ & $\begin{array}{c}\text { Std.Error of the } \\
\text { Estimate }\end{array}$ \\
\hline 1 & $.740^{\mathrm{a}}$ & .548 & .542 & 2.695 \\
\hline \multicolumn{2}{|l}{ a.Predictors: (Constant), Employee Relation } \\
\hline
\end{tabular}

Sumber: Data primer diolah(2019)

Berdasarkan Tabel 15 dapat diamati nilai adjusted $\mathrm{R}^{2}$ sebesar 0,542 berarti $54,8 \%$ perubahan (naik turun) pada motivasi kerja karyawan yang dipengaruhi oleh employee relation, sementara sisanya sejumlah $45,2 \%$ dipengaruhi oleh faktor - faktor lain diluar penelitian ini seperti variabel gaya kepemimpinan, dan variabel lingkungan kerja.

\section{KESIMPULAN}

Penerapan dari keseluruhan indikator-indikator pada employee relation di U Paasha Seminyak tergolong dalam kategori baik hal tersebut dibuktikan dari hasil keseluruhan rata-rata jawaban responden terkait program employee relation yaitu memperoleh rata-rata sebesar 3,19 yang dimana nilai rata-rata dari tanggapan karyawan tersebut berada dalam kategori setuju jadi hal 
tersebut menunjukan bahwa employee relation di U Paasha Seminyak dapat diterima serta dilaksanakan dengan baik oleh seluruh karyawan. Employee relation berpengaruh positif dan signifikan terhadap motivasi kerja karyawandi U Paasha Seminyak. Hal ini dilihat berdasarkan hasil analisis data menunjukan bahwa pengaruh employee relation terhadap motivasi kerja karyawan adalah pengaruh yang positif, hal ini diperoleh nilai signifikansi sebesar 0,000 kurang dari $0,05(0,000<0,05)$ dengan nilai koefisien regresi sebesar 0,626 bernilai positif dan nilai $\mathrm{t}$ hitung lebih besar dibandingkan t tabel $(9,726>1,991)$ mengindikasikan bahwa $\mathrm{H}_{0}$ ditolak dan $\mathrm{H}_{1}$ diterima. Hasil ini mempunyai arti bahwa employee relation berpengaruh positif dan signifikan terhadap motivasi kerja karyawan. Dengan kata lain semakin baik employee relation karyawan akan semakin meningkatkan motivasi kerja karyawan di U Paasha Seminyak.

\section{Ucapan terima kasih}

Penulis ingin mengucapkan terima kasih kepada semua pihak atas bimbingan dan segala bantuannya dalam menyelesaikan jurnal ini, yakni kepada :

1. Bapak Dr. Drs. I Nyoman Sunarta, M.Si., selaku Dekan Fakultas Pariwisata Universitas Udayana.

2. Bapak/Ibu Pembantu Dekan Fakultas Pariwisata Universitas Udayana yang membantu kelancaran perkuliahan.

3. Ibu Dra.A.A. Putri Sri, M.Si., selaku Ketua Program Studi Diploma IV Pariwisata, Fakultas Pariwisata Universitas Udayana

4. Bapak Agus Muriawan Putra, S.ST.Par., M Par., selaku Pembimbing I yang telah membantu memberikan bimbingan, saran, serta arahan sehingga laporan akhir ini dapat diselesaikan.

5. Ibu Putu Ratih Pertiwi, S.ST.Par., M.Par., M.Rech., selaku pembimbing II yang telah banyak meluangkan waktu untuk membimbing dan memberikan arahan dalam menyelesaikan laporan akhir ini.

6. Bapak Made Widiastana selaku Human Resource Manager di Hotel U Paasha Seminyak yang telah banyak membantu dalam proses pengumpulan data yang dibutuhkan dalam laporan akhir ini.

7. Seluruh karyawan di Hotel U Paasha Seminyak yang telah membantu pengumpulan data yang dibutuhkan dalam laporan akhir ini.

8. Kedua orang tua penulis yang telah memberikan dukungan, doa, dorongan serta biaya untuk menyelesaikan laporan akhir ini.

9. Teman-teman Diploma IV Pariwisata Reguler angkatan 2015 yang telah membantu penulis dalam menyelesaikan laporan akhir ini.

\section{DAFTAR PUSTAKA}

Andiyanto, Wilhemus dan Darmastuti, Ismi.2012. "Pengaruh Motivasi Kerja dan Kepempimpinan Terhadap Kinerja Karyawan Pegawai pada Badan Keluarga Berencana dan Pemberdayaan Perempuan Kabupaten Manggarai - Flores Nusa Tenggara Timur”. Tugas Akhir Fakultas Ekonomi Universitas Diponegoro Semarang.

Haibuan, Malayu. 2012. Manajemen Sumber Daya Manusia. Jakarta: Bumi Aksara.

Hermawan,J.2014. Pengaruh Pelaksanaan Kegiatan Employee Relation Terhadap Tingkat Motivasi Kerja Karyawan (Studi Terhadap Pelaksanaan Kegiatan Family Gathering dan Outbond Karyawan PT. UNINDO)".

Puspitasari, Rita. 2014. "Pengaruh Motivasi Kerja dan Pelatihan Terhadap Kinerja Karyawan pada Kantor Pelayanan Pajak Pertama Magelang". Tugas Akhir Program Studi Ilmu Akuntansi Universitas Negeri Yogyakarta

Ranggahita, Inggrid. 2012. "Pengaruh Pelaksanaan Employee Relation Terhadap Tingkat Motivasi Kerja Karyawan di Kusuma Said Price Hotel"

Rahayu, N.F. 2012. Aktivitas Employee Relation dan Kepuasan Kerja. Tugas Akhir Program Ilmu Komunikasi Universitas Sebelas Maret Surakarta.

Sariyuni, Arin. 2010. "Pengaruh Aktivitas Employee Relation Terhadap Loyalitas Karyawan Hotel Menara Peninsula Jakarta". 
Sidiq, Ahmad.2013. "Pengaruh Penilaian Karyawan Tentang Employee Relation Terhadap Tingkat Motivasi Kerja Hotel Gran Melia Jakarta".

Sugiyono.2016. Metode Penelitian Kuantitatif Kualitatif dan R\&D. Bandung: Alfabeta 